VOX PATRUM 24 (2004) t. 46-47

Bożena IWASZKIEWICZ-WRONIKOWSKA

(Lublin, KUL)

\title{
NAJSTARSZE PRZEDSTAWIENIA PIOTRA APOSTOłA A PROBLEM PRYMATU PAPIESKIEGO
}

Na ścianie tzw. baptysterium w Dura Europos zachowało się malowidło (ok. poł. III w.) ${ }^{1} \mathrm{z}$ wyobrażeniem Piotra, idącego po wodach morza i Chrystusa, który ratuje go przed utonięciem (il. 1$)^{2}$. W tym najstarszym zachowanym do naszych czasów przedstawieniu Apostoła ${ }^{3}$ badacze widzą na ogół treść wyłącznie chrystologiczną ${ }^{4}$. Miejscem narodzin ikonografii Piotrowej były natomiast najprawdopodobniej rzymskie warsztaty kamieniarskie ${ }^{5}$. Na początku IV wieku w reliefach dekorujących produkowane tam sarkofagi pojawiły się przedstawienia innych wydarzeń z życia Apostoła. Ani czas, ani miejsce powstania

${ }^{1}$ Por. P.V.C. Baur, The Paintings in the Christian Chapel, Reprinted from preliminary report of Fifth Season of Work (october 1931 - march 1932) of the Excavations at Dura-Europos conducted by Yale University and the French Academy of Inscriptions and Letters, New Haven 1934, 249. Zdaniem niektórych badaczy pomieszczenie to pełniło raczej funkcję martyrium, zob. tamże, s. 255.

${ }^{2}$ Por. Mt 14, 29-31: „Piotr wyszedł z łodzi i krocząc po wodzie przyszedł do Jezusa. Lecz na widok silnego wiatru uląkł się i gdy zacząl tonąć, krzyknąl: «Panie, ratuj mnie»! Jezus natychmiast wyciągnął rękę i chwycił go, mówiąc: "Czemu zwątpiłes, małej wiary»? [cytaty biblijne wg Biblii Tysiąclecia]. Późniejsze przedstawienia sceny o tej samej tematyce - m.in. na pokrywie sarkofagu z pochodzącej z 1 . ćwierćwiecza IV wieku trichory na cmentarzu Kaliksta, zob. G. Bovini - H. Brandenburg - F.W. Deichmann, Repertorium der christlich-antiken Sarkophage. Rom-Ostia, Wiesbaden 1967 (dalej cyt. Rep.), nr 365; G. Stuhlfauth, Die apokryphischen Petrusgeschichten in der altchristlichen Kunst, Berlin - Leipzig 1925, 9-13; M. Sotomayor, S. Pedro en la iconografia paleocristiana. Testimonios de la tradición cristiana sobre San Pedro en los monumentos iconograficos anteriores al siglo sexto, Granada 1962, 17 i 153-156; A. Donati (red.), Pietro e Paolo. La storia, il culto, la memoria nei primi secoli, Catalogo della mostra (Roma, Palazzo della Cancelleria 30 giugno - 10 dicembre 2000), Milano 2000, nr 43, s. 124 i 206.

3 Por. Baur, The Paintings in the Christian Chapel, s. 266-270.

${ }^{4}$ Por. np. E. Dinkler, Die erste Petrusdarstellungen. Ein archäologischer Beitrag zur Geschichte des Petrusprimates, „Marburger Jahrbuch für Kunstwissenschaft” 11 (1939) 14; Sotomayor, S. Pedro en la iconografia paleocristiana, s. 17.

${ }^{5}$ Z Rzymu bowiem pochodzą najstarsze zachowane przedstawienia (zob. niżej); nie można jednak wykluczyć, że w tym samym czasie wizerunki tak Piotra, jak i Pawła powstawały też na Wschodzie, na co zdają się wskazywać wzmianki w dziełach Euzebiusza z Cezarei (HE VII 18, 4; Epistola ad Constantiam Augustam, PG 20,1547). Musiały to być jednak wyobrażenia o innym charakterze, raczej nawiązujące do tradycji portretowania slynnych ludzi, niż lansujące jaką́s ideę. 
tych obrazów nie wydają się przypadkowe. Wiele bowiem wskazuje, że właśnie w Rzymie kształtowało się w tamtym stuleciu wyobrażenie o wyjątkowej roli, jaką Piotr, założyciel rzymskiej wspólnoty, spełniać miał również w Kościele powszechnym ${ }^{6}$. Ikonografia była wówczas i narzędziem, i odzwierciedleniem kolejnych etapów tego procesu, w którym, jak się wydaje, można wyodrębnić dwie fazy, znajdujące swój wyraz w przedstawieniach.

I.

Pierwsza połowa IV wieku przynosi liczne i zróżnicowane tematycznie wyobrażenia Piotra na sarkofagach jednofryzowych, na których na ogół sąsiadują z innymi przedstawieniami wydarzeń ewangelicznych (il. 2$)^{7}$. Są to przede wszystkim sceny ukazujące znane $\mathrm{z}$ apokryfów rzymskie epizody z życia Apostoła $^{8}$ - jego aresztowanie ${ }^{9}$ oraz dokonany $w$ więzieniu cud wyprowadzenia wody ze skały ${ }^{10}$. W pierwszym obrazie dwaj żołnierze prowadzą Piotra za ręce, podczas gdy ich towarzysz pochyla się przed Apostołem w głębokim ukłonie (proskynesis) $)^{11}$. Drugi temat pokazany jest zgodnie ze schematem wypracowanym już $\mathrm{w} 1$. poł. III wieku w malarstwie katakumbowym dla przedstawień cudu źródła dokonanego przez Mojżesza w drodze przez pustynię (Wj 16, 6) - mężczyzna, ubrany w tunikę lub pallium, dotyka paleczką

${ }^{6}$ Por. K. Schatz, Prymat papieski od poczq̨tków do wspótczesności, tlum. E. Marszal J. Zakrzewski, Kraków 2004, 17-67.

${ }^{7}$ Np. sarkofag Sabinusa (Musei Vaticani), datowany na 310-330 r. (Rep. nr 6). Przykładem jeszcze wcześniejszym są reliefy na znalezionym w rejonie Watykanu (obecnie w Musei Vaticani) tzw. sarkofagu Jonasza, datowanym na koniec III/pocz. IV wieku (Rep. nr 35; Donati, Pietro e Paolo, nr 46, s. 126 i 206n), jednak różnią się one w szczególach od przedstawień późniejszych.

${ }^{8} \mathrm{Nie}$ wszyscy badacze są zgodni, co do apokryficznej genezy tych scen, zob. np. Ch. Pietri, Roma christiana. Recherches sur l'origine de l'Eglise de Rome, son organisation, sa politique, son idéologie de Miltiade à Sixte III (311-440), Rome 1976, s. 337n. Również ich interpretacje, proponowane w literaturze przedmiotu, bywają bardzo różne, niekiedy świadcząc o wybujałej fantazji autorów. Nie miejsce tu jednak ani na ich prezentację, ani na uzasadnianie wyboru, jakiego musialam dokonać decydując się na przyjęcie tych, które uznałam za najbardziej przekonujące.

9 Por. Acta Petri 36, 7; W. Schneemelcher - E. Hennecke, Neutestamentliche Apokryphen, II, Tübingen 1964, 219; Stuhlfauth, Die apokryphischen Petrusgeschichten, s. 72-126.

${ }^{10}$ Ta opowieść zachowała się w znacznie późniejszym Martyrium s. Petri 5 autorstwa PseudoLinusa (ed. R.A. Lipsius - M. Bonnet, Acta Apostolorum Apocrypha, I, Leipzig 1891, 6-7) i w Aktach Processusa i Martinianusa 2 (ASS Julii I 270): „beatus Petrus in monte Tarpeio signum expressit in eadem custodia, atque eadem hora emanarunt aquae e monte [...]". Można jedynie domyślać się, że jej wcześniejsze wersje, z których czerpać mogli artyści IV-wieczni, nie zachowały się, zob. Stuhlfauth, Die apokryphischen Petrusgeschichten, s. 50-71; P. van Moorsel, Il miracolo della roccia nella letteratura e nell'arte paleocristiana, RivAC 40 (1964) 236-251.

${ }^{11}$ Ten detal, niezrozumialy $w$ scenie aresztowania, próbuje się interpretować również $w$ inny sposób - np. F. Bisconti (Pietro e Paolo: l'invenzione delle immagini, la rievocazione delle storie, la genesi delle teofanie, w: Donati, Pietro e Paolo, s. 207) widzi tu ucieczkę Piotra z więzienia. 
wznoszącej się obok skały, po której spływa woda ${ }^{12}$. W scenach Piotrowych pojawia się jednak dodatkowy motyw ${ }^{13}$, który pozwala odróżnić je od przedstawień Mojżesza ${ }^{14}$. Otóż, wodę spływającą po skale piją rzymscy żołnierze, w charakterystycznych krótkich tunikach i czapkach (tzw. pileus pannonicus) ${ }^{15}$. Zdaniem Charlesa Pietri, Piotr występuje tu, zgodnie $\mathrm{z}$ typologią szeroko stosowaną $w$ literaturze patrystycznej, jako nowy Mojżesz, przywódca ludu Nowego Przymierza i głosiciel Nowego Prawa. Żołnierzy gaszących (duchowe) pragnienie Pietri uważa za personifikację tego ludu, pokazanego jako Militia Christi ${ }^{16}$. Inni badacze są raczej skłonni widzieć w nich znanych z opowieści apokryficznych strażników więziennych nawróconych przez Piotra ${ }^{17}$.

Wykonawcy rzymskich sarkofagów dość wcześnie zaczęli uzupełniać obie wspomniane kompozycje o tzw. scenę z kogutem: obok podnoszącego trzy palce Jezusa stoi Apostoł, który na ogół kładzie swój palec na brodzie, co w starożytnej mowie gestów było wyrazem zakłopotania (il. 3$)^{18}$. Stałym atrybutem tych przedstawień jest kogut, który nawiązuje do znanej $z$ ewangelii opowieści o trzykrotnym zaparciu się Piotra (Mt 26, 69-75; Mk 14, 66-72; Łk $22,54-62 ; \mathrm{J} 18,17-27)^{19}$. Badania wykazały, że wymowę sceny z kogutem można uważać w równej mierze za Piotrową, jak i za chrystologiczną ${ }^{20}$. Pokazuje ona bowiem nie tyle fakt zaparcia się Piotra, co raczej trzykrotne wyznanie miłości do Jezusa ${ }^{21}$ oraz wiarę w Jego boskość i mesjańską misję (Mt 16, 15n.; Mk 8,29; Łk 20) ${ }^{22}$, nawiązując tym samym nie tylko do jego upadku i apostazji,

12 Por. B. Wronikowska, Picturae sacrae, Lublin 1990, 114-117.

13 Np. na tzw. sarkofagu Sabinusa, por. Rep. nr 6; Sotomayor, S. Pedro en la iconografia paleocristiana, s. 19, 22n, 62, 66, 97; Donati, Pietro e Paolo, nr 50, s. 129 i 208-210.

14 Niekiedy scenie towarzyszy napis - PETRVS, por. R. Garrucci, Storia dell'arte cristiana nei primi otto secoli della Chiesa, III, Prato 1876, tabl. 179, 9.

15 Por. A. De Waal, Zur Klärung einer noch unerklärten Szene auf einem later. Sarkophag, RQ 25 (1911) 137-148; P. Styger, Neue Untersuchungen über die altchristlichen Petrusdarstellungen, RQ 27 (1913) 17-74.

16 Por. Pietri, Roma christiana, s. 317-401.

${ }_{17}$ Por. P.Testini, Gli apostoli Pietro e Paolo nella più antica iconografia cristiana, w: Studi Petriani, Roma 1968, 113.

${ }^{18} \mathrm{~Np}$. na sarkofagu ze scenami z Nowego Testamentu (Rzym, Museo Nazionale), datowanym na pierwszą tercję IV wieku, por. Rep. nr 770; Donati, Pietro e Paolo, nr 47, s. 127 i 207.

19 Por. Mt 26, 74: „Wtedy począł się zaklinać i przysięgać: «Nie znam tego Czlowieka». I w tej chwili kogut zapiał. Wspomniał Piotr na słowa Jezusa, który mu powiedzial: «Zanim kogut zapieje, trzy razy się Mnie wyprzesz». Wyszedł na zewnątrz i gorzko zaplakal".

${ }^{20}$ Por. m.in. J. Gruszczyk, Tzw. „scena zaparcia się Piotra” w sztuce wczesnochrześcijańskiej, Lublin 1997 (praca magisterska napisana w Katedrze Historii Sztuki Starożytnej i Wczesnochrześcijańskiej KUL, maszynopis).

21 Por. J 21, 15: „Rzekł Jezus do Szymona Piotra: «Szymonie, synu Jana, czy miłujesz Mnie więcej aniżeli ci»? Odpowiedział Mu: «Tak, Panie, Ty wiesz, że Cię kocham». Rzekł do niego: «Paś baranki moje»".

${ }^{22}$ Por. Mt 16, 16: „Jezus zapytal ich: «A wy za kogo Mnie uważacie»? Odpowiedzial Szymon Piotr: «Ty jesteś Mesjasz, Syn Boga żywego»". 
lecz i do przełomowego w dziejach Kościoła wydarzenia, jakim było przekazanie mu kluczy do królestwa niebieskiego ${ }^{23}$.

Około połowy IV wieku repertuar Piotrowy wzbogaciły przedstawienia ukazujące Apostoła siedzącego na kamieniu, w otoczeniu drzew, $\mathrm{z}$ otwartym zwojem w dłoniach, a więc w trakcie lektury. Przysłuchuje się jej kilku wyraźnie zainteresowanych żołnierzy, tych samych (lub takich samych), jakich widzieliśmy i w innych, wspomnianych wyżej, przedstawieniach Piotrowych (il. 4$)^{24}$. Scenę tę, nazywaną często Cathedra Petri ${ }^{25}$, uważa się za symbol nauczania apostolskiego. Uosabia je pogrążony w lekturze, pokazany zgodnie $\mathrm{z}$ typem ikonograficznym właściwym przedstawieniom filozofów i nauczycieli ${ }^{26}$, założyciel rzymskiego Kościoła i jego pierwszy biskup ${ }^{27}$. W IV wieku, w którym autorytet tego Kościoła w świecie rozprzestrzeniającego się chrześcijaństwa stawał się coraz bardziej oczywisty ${ }^{28}$, osoba Piotra i powierzona mu misja przemawiały na rzecz przeświadczenia, że na straży tradycji, czyli przekazywania (traditio) apostolskiej nauki, siłą rzeczy stać musi jego następca, biskup Kościoła rzymskiego.

Piotr Apostol przedstawiany był z tak dużą częstotliwością, że uważa się go, obok Jezusa, za postać najbardziej popularną w ikonografii wczesnochrześcijańskiej $^{29}$. Przedstawienia $\mathrm{z}$ jego udziałem stanowią pendant dla scen chrystologicznych $^{30}$, a niekiedy zajmują centralne miejsce w kompozycjach: dotyczy to zwła-

${ }^{23}$ Por. Mt 16, 17-19: „Na to Jezus mu rzekł: «Błogosławiony jesteś, Szymonie, synu Jony [...]. Otóż i Ja tobie powiadam: Ty jesteś Piotr [czyli Skała], i na tej Skale zbuduję Kościół mój, a bramy piekielne go nie przemogą. I tobie dam klucze królestwa niebieskiego: cokolwiek zwiążesz na ziemi, będzie związane w niebie, a co rozwiążesz na ziemi, będzie rozwiązane w niebie»,..

${ }^{24}$ Żołnierze również tutaj mogą być personifikacją ludu Bożego (Militia Christi). Przez niektórych badaczy są identyfikowani z pilnującymi Piotra w więzieniu strażnikami. Pod wpływem późniejszej legendy, przekazanej przez apokryficzne Martyrium s. Petri a Lino episcopo conscriptum (zob. P. Franco de' Cavalieri, Come $i$ ss. Processo e Martiniano divennero i carcerieri dei principi degli apostoli?, ST 22:1909, 35-39), utożsamiono ich z męczennikami Processusem i Martinianusem, por. Stuhlfauth, Die apokryphischen Petrusgeschichten, s. 35-50.

${ }^{25}$ Stuhlfauth, Die apokryphischen Petrusgeschichten, s. 35-50; J. Wilpert, I sarcofagi cristiani antichi, I, Rom 1929, 185-192 (dalej cyt. WS).

${ }^{26}$ Por. H.I. Marrou, Mousikos aner. Études sur les scènes de la vie intellectuelle figurant sur les monuments funéraires romains, Grenoble 1938 (repr. Roma 1964), 114-121.

${ }^{27}$ Por. Dinkler, Die erste Petrusdarstellungen, s. 78: „wird jetzt Petrus in seinem Amt als der Lehrer der römischen Gemeinde in einer bekenntnismäßigen Repräsentationsszene wiedergeben werden"; Th. Klauser, Die Cathedra im Totenkult der heidnischen und christlichen Antike, Münster i. W. $1927,178-183$

${ }^{28}$ Świadczą o tym między innymi wypowiedzi biskupów innych Kościołów, którzy na synodzie w Arles (314) ogłosili, że Rzym jest źródłem tradycji i apostolskiego nauczania, por. Epistola synodi Arelatensis ad Silvestrum papam, Mansi II 469C; Pietri, Roma christiana, s. 301-306; Schatz, dz. cyt., s. $17-67$.

${ }^{29}$ Por. WS, testo, s. 107; Testini, Gli apostoli Pietro e Paolo, s. 108.

${ }^{30} \mathrm{~Np}$. tzw. sarkofag dogmatyczny (Musei Vaticani), por. Rep. nr. 43; L. De Bruyne, L'iconographie des apôtres Pierre et Paul dans une lumière nouvelle, w: Saecularia Petri et Pauli, 
szcza sceny z kogutem, która, zdaniem Louis De Bruyne, w 1. poł. IV wieku była jednym $z$ najważniejszych tematów $w$ dekoracji sarkofagów fryzowych ${ }^{31}$. Piotr jest zarazem jedną $\mathrm{z}$ niewielu postaci, którym twórcy tego okresu nadali indywidualne rysy, pozwalające go bez trudu zidentyfikować. Przedstawiany był jako mężczyzna w sile wieku, mocno zbudowany, o okrągłej twarzy, krótkich kręconych włosach i krótko przyciętej brodzie ${ }^{32}$. Takie wizerunki pojawiają się już na sarkofagach datowanych na czasy Dioklecjana (pocz. IV wieku) ${ }^{33}$. Wobec braku jakichkolwiek danych źródłowych na temat wyglądu Apostoła, były one całkowicie fikcyjne ${ }^{34}$, co zupełnie nie przeszkadzało odbiorcom, przyzwyczajonym do konwencjonalnych portretów osób publicznych ${ }^{35}$.

Częstość występowania i różnorodność tematyczna przedstawień Piotra to przekonujące dowody znaczenia, a także popularności Księcia Apostołów, zwłaszcza w środowisku rzymskim ${ }^{36}$. Erich Dinkler w opublikowanej w 1939

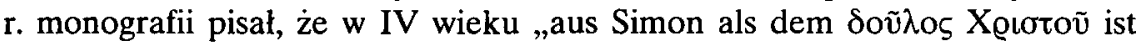
Petrus der vicarius Christi und der erste Bischof Roms geworden. Schon ist neben das eine Haupt der Kirche, neben Christus, ein zweites Haupt getreten: Petrus, der Fels der Kirche, der Begründer und Lehrer der römischen Cathedra"37. Czy można posunąć się jeszcze dalej i stwierdzić, że w ikonografii znajdujemy potwierdzenie prymatu Piotra także w Kościele powszechnym? Odpowiedź na to pytanie nie może już być tak jednoznaczna, zwlaszcza wobec zmian, jakie zaszły $w$ przedstawieniach Piotrowych $w$ drugiej fazie interesującego nas procesu - i w ikonografii, która już w mniejszym niż wcześniej stopniu sięgała do typologii, większą wagę przywiązując do wymowy teologicznej i w rzymskiej

Città del Vaticano 1969,52: „Nous sommes en effet dans une période, où pour la première fois dans l'histoire de l'art, on conçoit l'idée de doubler l'iconographie du Christ d'une iconographie dédiée à son Vicaire".

31 Por. De Bruyne, L'iconographie des apôtres Pierre et Paul, s. 46-77.

32 Charles Pietri (Roma christiana, s. 271) pisal, ze jest to ,un homme dont le visage porte les traces et les souffrances d'une rude maturité". Na zasadzie kontrastu zbudowany jest wizerunek Pawła, którego od połowy IV wieku pokazuje się, nawiązując do portretów antycznych filozofów, jako intelektualistę o pociąglej, niekiedy ascetycznej, twarzy z długą brodą, por. F. Gerke, Petrus und Paulus, zwei bedeutende Köpfe im Museum von S. Sebastiano, RivAC 10 (1933) 307-329.

33 Por. Gerke, Petrus und Paulus, zwei bedeutende Köpfe, s. 311.

34 Por. E. Stommel, Beiträge zur Ikonographie der konstantinischen Sarkophagplastik, Bonn 1954, 115n; Testini, Gli apostoli Pietro e Paolo, s. 105; Bisconti, Pietro e Paolo: l'invenzione delle immagini, s. 44: „sono rappresentazioni ideali".

${ }_{35}$ Por. A. Grabar, Les voies de la création en iconographie chrétienne, Paris 1979, 59-82.

${ }^{36}$ Rzymska proweniencja większości zabytków z przedstawieniami św. Piotra nie podlega dyskusji - zob. Testini, Gli apostoli Pietro e Paolo, s. 108: „Da pitture, mosaici, sculture, oggetti in avorio, metallo e terracotta, stoffe e vetri incisi e a fondo d'oro del IV e V secolo [...] si ha una totale di 533 rappresentazioni sicure di Pietro, di cui 353 spettano a Roma". Liczne przykłady rzymskiej proweniencji wczesnochrześcijańskich przedstawień Piotra w wielu miejscach swego dzieła podaje Ch. Pietri (Roma christiana, passim).

${ }^{37}$ Dinkler, Die erste Petrusdarstellungen, s. 78. 
eklezjologii, która coraz silniej eksponowała wyjątkową rolę Kościoła Rzymu jako stolicy apostolskiej (sedes apostolica) ${ }^{38}$. Przejawem zmian była swego rodzaju dwutorowość, którą obserwować można w ogromnej liczbie zachowanych zabytków: obok obrazów, dość wyraźnie lansujących ideę Piotra, któremu Chrystus powierzył rolę głowy Kościoła, pojawiły się kompozycje eksponujące znaczenie obu książąt Apostołów - i Piotra, i Pawła.

II.

W 2. poł. IV stulecia Piotr nadal należal do ulubionych postaci ikonografii chrześcijańskiej. Zanikały wprawdzie powoli tematy, które występowały w okresie wcześniejszym - tzw. trylogia Piotra (aresztowanie, cud źródła i scena $\mathrm{z}$ kogutem) oraz Cathedra Petri, ale równocześnie na sarkofagach pojawiły się nowe sceny $z$ udziałem Piotra: umycie mu nóg przez Jezusa ${ }^{39}$, rozmowa $\mathrm{z}$ psem Szymona Maga przed domem senatora Marcellusa ${ }^{40}$, uwolnienie $z$ więzienia przez anioła ${ }^{41}$, wskrzeszenie Tabity ${ }^{42}$ oraz ukaranie Ananiasza i Safiry ${ }^{43}$. Te same wątki występowały na wyrobach rzemiosła artystyczne-

${ }^{38}$ Por. Pietri, Roma christiana, s. 1505-1515.

39 Por. J 13, 5n: „Potem nalał wody do miednicy. I zaczął umywać uczniom nogi i ocierać prześcieradłem, którym był przepasany. Podszedł więc do Szymona Piotra [...]". Przedstawienie zachowane m.in. na tzw. sarkofagu pasyjnym (Musei Vaticani), datowanym na lata $380-400$, por. Rep. nr 58; WS tabl. 1, 2, 4, 5; 16, 1-2; 20, 5; 121, 1; Sotomayor, S. Pedro en la iconografia paleocristiana, s. 102, 105, 109-111, 127, 183; Donati, Pietro e Paolo, nr 49, s. 128 i 208.

${ }^{40}$ Por. Acta Petri 9, Schneemelcher - Hennecke, Neutestamentliche Apokryphen, s. 200, thum. M. Michalski, ALP I 57: „Piotr udał się do domu Marcellusa, gdzie przebywał Szymon. [...]. I spostrzegł Piotr psa wielkiego, uwiązanego na długim łańcuchu, i podszedłszy do niego, spuśil go. A znalazłszy się na wolności pies począl zaraz przemawiać glosem ludzkim i odezwał się do Piotra: «Co rozkażesz mi czynić, sługo niewypowiedzianego Boga żywego»?". Przedstawienia zachowane na sarkofagach: z katedry w Mantui (WS, tabl. 30); z Werony (WS, tabl. 150, 2; Sotomayor, S. Pedro en la iconografia paleocristiana, il. 32), z krzeszowickiej kolekcji Potockich (Muzeum Czartoryskich w Krakowie), zob. J.A. Ostrowski, Apocryphal and canonical Scenes. Some remarks on the Iconography of the Sarcophagus from the Collection of the National Museum in Cracow, „Etudes et Travaux” 13 (1983) 305-309; Stuhlfauth, Die apokryphischen Petrusgeschichten, s. 3-9

${ }^{41}$ Por. Dz 12, 6n.: „W nocy, po której Herod miał go wydać, Piotr, skuty podwójnym lańcuchem, spał między dwoma żołnierzami, a strażnicy przed bramą strzegli więzienia. Wtem zjawil się anioł Pański i światłość zajaśniała w celi". Przedstawienie zachowane $\mathrm{m}$. in. na sarkofagu z Fermo (WS 116, 3; Testini, Gli apostoli Pietro e Paolo, tabl.V, 2).

${ }^{42}$ Por. Dz 9, 40n: „Piotr upadl na kolana i modlił się. Potem zwrócil się do ciała i rzekt: «Tabito, wstań». A ona otwarła oczy i zobaczywszy Piotra, usiadła". Przedstawienie zachowane m.in. na sarkofagu z St. Maximin w Prowansji (WS I, tabl. 145, 6-5).

${ }^{43}$ Por. Dz 5, 1-11: „Pewien czlowiek, imieniem Ananiasz, z żona swoją Safira, sprzedali posiadłość i za wiedzą żony odłożył sobie częsć zapłaty, a pewną część przyniósł i złożyl u stóp Apostołów. «Ananiaszu - powiedział Piotr - dlaczego szatan zawładnął twym sercem, że skłamałeś 
go $^{44}$ - szkłach złoconych ${ }^{45}$, lampkach oliwnych ${ }^{46}$ i relikwiarzach ${ }^{47}$. Na ogól w przedstawieniach tych dominuje anegdota, która miała zaspokoić szczególnego rodzaju zainteresowanie, charakterystyczne dla szerokich kręgów wiernych $\mathrm{z}$ warstw ludowych. Obok nich pojawiły się jednak w tym czasie także przedstawienia, w których próbowano przekazywać glębsze treści. Należy do nich Piotr niosący krzyż (stauroforos) ${ }^{48}$ oraz przekazanie Piotrowi kluczy

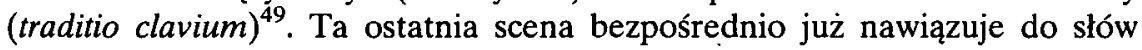
przytoczonych w ewangelii Mateusza: „I Tobie dam klucze ...” (Mt 16, 18).

Klucze do królestwa niebieskiego i powierzona Apostołowi władza związywania i rozwiązywania są symbolem wyjątkowej pozycji Piotra jako opoki, na której opiera się Kościół Chrystusowy. W wypowiedziach ówczesnych autorytetów religijnych, w tym i kolejnych biskupów Rzymu, chętnie podkreślających paralelę między ich urzędem a misją Piotra ${ }^{50}$, można dostrzec wyraz przekonania, że byl on też fundamentem Kościoła powszechnego ${ }^{51}$. Temat traditio clavis dość szybko jednak zniknął $\mathrm{z}$ repertuaru przedstawień Piotra ${ }^{52}$.

Ponieważ, jak zauważył Pietri, „l'iconographie reflète obscurément une évolution des mentalités dans la société chrétienne" że język, jakim przemawiali wówczas chrześcijańscy twórcy, świadczyć musi o innym, niż wcześniej postrzeganiu postaci Piotra, albo przynajmniej jego miejsca w eklezjologii. Argumentem na rzecz tego przypuszczenia jest powsta-

Duchowi Świętemu i odłożyłeś sobie część zapłaty za ziemię»,.. Przedstawienie zachowane m. in. na Lipsanotece z Brescii, por. J. Kollwitz, Die Lipsanotek von Brescia, Leipzig 1933).

44 Por. P. Testini, L'iconografia degli apostoli Pietro e Paolo nelle cosidette 'arti minori', w: Saecularia Petri et Pauli, s. 243-323.

${ }^{45}$ Np. szklo zlocone z Museo Sacro del Vaticano, datowane na IV wiek, por. F. Zanchi Roppo, Vetri paleocristiani a figure d'oro, Bologna 1967, n. 200; Sotomayor, S. Pedro en la iconografia paleocristiana, s. 195, 257n; Donati, Pietro e Paolo, nr 44, s. 125 i 206).

${ }^{46} \mathrm{~Np}$. lampa brązowa z Museo Archeologico we Florencji, datowana na koniec IV wieku, por. Testini, L'iconografia degli apostoli Pietro e Paolo nelle cosidette 'arti minori', nr 48, s. 265 i 298; Donati, Pietro e Paolo, nr 45, s. 125 i 206. 260.

${ }^{47}$ Por. Testini, L'iconografia degli apostoli Pietro e Paolo nelle cosidette 'arti minori', s. 251-

$48 \mathrm{~Np}$. Sarkofag kolumienkowy, znaleziony w $1607 \mathrm{r}$. podczas budowy Bazyliki św. Piotra na Watykanie, datowany na końcową tercję IV wieku, por. Rep. nr 679.

${ }^{49}$ Np. Sarkofag w Museo di S. Sebastiano (Rep. nr. 464); inne przykłady por. Pietri, Roma christiana, s. 1442-1459.

${ }^{\text {so }}$ Cytuje je Pietri, Roma christiana, m.in. s. 1454-1466, 1515-1523.

51 Ambrozjaster (In Epistolam ad Galatas I 18, 1, CSEL 81/3, 15) pisat w tym samym czasie o Piotrze: „Primus inter apostolos, cui delegaverat Salvator curam Ecclesiarum”, a Jan Chryzostom (Oratio in S. Ignatium 4, PG 50, 591): „Quem toti orbi terrarum praefecit, Petrum, cui claves regni caelorum dedit, cuius arbitrio et potestati cuncta permisit [...]".

52 Sarkofagi, w których dekoracji występuje Piotr trzymający klucze, lub odbierający je $z$ rąk Jezusa, ustawiano początkowo przede wszystkim w pobliżu miejsc kultu Piotra na Watykanie i ad catacumbas, por. Pietri, Roma christiana, s. 1442.

${ }^{53}$ Pietri, Roma christiana, s. 1413. 
nie około połowy IV wieku typu ikonograficznego, który, przy pomocy znaków zaczerpniętych z ikonografii cesarskiej ${ }^{54}$, pokazuje Piotra w nowej, teologicznej perspektywie i w nowym, monumentalnym kontekście budowli bazylikalnej. Po raz pierwszy typ ten pojawil się prawdopodobnie w absydzie Bazyliki św. Piotra na Watykanie, gdzie przedstawiono, na tle rajskich motywów, brodatą postać stojącego na pagórku Chrystusa ${ }^{55}$, ukazanego jako władca, który prawą rękę unosi w geście triumfu, a w lewej trzyma rozwinięty zwój. Ku Chrystusowi zwracają się flankujący Go Apostołowie - Paweł, wyrażający gestem aklamację oraz pochylony $w$ ukłonie Piotr, $z$ krzyżem na ramieniu i dłońmi owiniętymi skrajem płaszcza (il. 5) ${ }^{56}$. Mozaika watykańska uległa zniszczeniu w końcu XVI wieku, przetrwały natomiast liczne obrazy, które ją naśladowały. W 2. poł. IV stulecia scena ta stała się bowiem jednym $\mathrm{z}$ głównych tematów w reliefach sarkofagowych $^{57}$, a spotkać ją można było także w baptysteriach ${ }^{58}$ i na licznych wyrobach rzemiosła artystycznego ${ }^{59}$. Do najstarszych zachowanych przykładów należy sarkofag z S. Sebastiano ${ }^{60}$, gdzie występują wszystkie elementy kompozycji, którą przywykło się określać jako traditio legis (il. 6), ponieważ wielu badaczy widziało w niej przekazanie (traditio) przez Chrystusa Prawa (lex) Piotrowi i potwierdzenie tym samym jego przywódczej roli w Kościele ${ }^{61}$. Ta interpretacja do dziś uporczywie powraca w opracowaniach, chociaż od

${ }^{54}$ Por. W.N. Schumacher, „Dominus legem dat”, RQ 54 (1959) 2-8.

${ }^{55}$ M. Sotomayor (Úber die Herkunft der "Traditio legis", RQ 56:1961, 215-230) uważa, że pierwowzorów sceny szukać należy na sarkofagach, a nie w bazylice. Bardziej przekonują jednak, moim zdaniem, argumenty zwolenników tezy o genezie bazylikalnej. Dyskusja nad powstaniem kompozycji i rolą mozaiki z Watykanu jako ewentualnego pierwowzoru, por. Pietri, Roma christiana, s. 1414-1419.

${ }^{56} \mathrm{~W}$ dolnym pasie kompozycji prawdopodobnie znajdowal się fryz z kroczących baranków. Różne propozycje rekonstruowania mozaiki, por. B. Filarska, Archeologia chrześcijańska, Warszawa 1999, 91-93.

57 Por. m.in. Rep. nr 28, 57, 58, 200, 675, 678, 1008; inne przykłady zob. Pietri, Roma christiana, s. $1420-1437$.

${ }^{58} \mathrm{~Np}$. w S. Giovanni in Fonte (Neapol), por. J.L. Maier, Le baptistère de Naples et ses mosaïques, Fribourg 1964, 108n. Zdaniem L. De Bruyne (La décoration des baptistères paléochrétiens, w: Actes du Ve Congrès international d'archéologie chrétienne, Roma 1957, 341-369) właśnie w baptysteriach szukać należy genezy przedstawień tego typu.

so Por. Pietri, Roma christiana, s. 1422n.

${ }^{60}$ Por. Rep. nr 200 . Testini zwrócil uwagę na zapewne nieprzypadkowe sąsiedztwo miejsca znalezienia tych sarkofagów z miejscami kultu Piotra i Pawła na Watykanie i ad catacumbas - zob. tenże, La lapide, s. 729. Liczne przykłady sąsiadowania sarkofagow dekorowanych scenami Piotrowymi z miejscami jego kultu podaje Pietri, Roma christiana, s. 329n, 342n, 1420n.

${ }^{61}$ Por. np. K. Wessel, Das Haupt der Kirche. Zur Deutung ausgewählter frühchristlicher Bildwerke, „Archäologischer Anzeiger” (1950/1951) 298-323; E. Josi, Pietro Apostolo. Iconografia. 1. Archeologia, ECat IX 1417-1420; C. Davis-Weyer, Das Traditio-Legis-Bild und seine Nachfolge, „Münchener Jahrbuch der Bildenden Kunst” 11 (1961) 7-45. Przegląd publikacji gloszących ten pogląd zob. Y.M. Congar, Le thème du don de la Loi dans l'art paléochrétien, „Nouvelle Revue Théologique" 84 (1962) 920. 
blisko stulecia jest krytykowana przez najwybitniejszych znawców wczesnochrześcijańskiej ikonografii ${ }^{62}$. Paweł Styger już w 1913 roku zauważył, że Chrystus co prawda trzyma zwój, lecz go Piotrowi nie wręcza, zaś towarzyszący niekiedy scenie napis Dominus legem dat mówi o gloszeniu Prawa, a nie o przekazywaniu go Piotrowi ${ }^{63}$. Inni autorzy zwracali uwage na kolejne detale, które wykluczają obecność motywu traditio - np. stojąca na ogół postawa Chrystusa, właściwa raczej scenie adlocutio ${ }^{64}$, lub zwój w postaci rozwiniętej, charakterystyczny dla przedstawień ukazujących odczytywanie tekstu, a nie przekazywanie dokumentu ${ }^{65}$, itd. Pisano na ten temat wiele, ale autorem, który wykazał w sposób nie budzący wątpliwości, że celem artystów nie było nawiązanie do idei prymatu Piotra, lecz ukazanie w pierwszym rzędzie objawienia zmartwychwstałego Chrystusa, był W.N. Schumacher ${ }^{66}$. Od czasu ukazania się w 1954 roku jego artykułów, zebrano już dostatecznie wiele kolejnych argumentów na rzecz tezy o znacznie szerszej, chrystologicznej, a nie Piotrowej wymowie przedstawieńt ${ }^{67}$.

Przytoczona interpretacja nie pomniejsza bynajmniej roli Piotra, który nie przypadkowo był pierwszym naocznym świadkiem zmartwychwstania ${ }^{68}$. W I liście do Koryntian czytamy, że kiedy Chrystus ,zmartwychwstał trzeciego dnia, zgodnie z Pismem, ukazał się Kefasowi, a potem Dwunastu, później zjawił się więcej niż pięciuset braciom równocześnie..." $(15,4)$. Niosąc krzyż ${ }^{69}$ i wy-

${ }^{62}$ Por. np. A. Giuliani, Il primato di S. Pietro nell'iconografia paleocristiana (secoli II-IV), Roma 1965, 18: „Gesù lascia effettivamente e definitivamente a $S$. Pietro il governo della Chiesa” (nota bene, autor najwyraźniej nie znając podstawowej literatury przedmiotu, opiera się na opracowaniach już w jego czasach przestarzałych i z nich czerpie wiedzę, m.in. na temat chronologii zabytków, skutkiem czego ta publikacja o bardzo obiecującym tytule okazuje się zupełnie nieprzydatna do badań nad interesującym nas problemem); J.C. Kałużny, Ksztattowanie się przedstawień chrystologicznych jako świadectwo ideowych przemian w Kosciele III i IV wieku, Kraków 2004 (= „Studia Laurentiana”, Supl. 1), 156n; Schatz, dz. cyt., s. 54: „Na mozaice absydy dawnego kościoła sw. Piotra, apostol przedstawiony jest w momencie przyjmowania od Chrystusa tablic Nowego Przymierza" (sic!).

${ }^{63}$ Styger, Neue Untersuchungen über die altchristlichen Petrusdarstellungen, s. 17-74.

64 Por. Schumacher, „Dominus legem dat", s. 2 n.

65 Por. Th. Birt, Die Buchrolle in der Kunst. Archaeologisch-Antiquarische Untersuchungen zum Antiken Buchwesen, Leipzig 1907, 185; Schumacher, „Dominus legem dat”, s. 8n; Pietri, Roma christiana, s. 1428.

66 Por. Schumacher, „Dominus legem dat”, s. 1-39; tenże, Eine römische Apsiskomposition, RQ 54 (1959) 137-202; Congar, art. cyt., s. 915-933.

67 Por. Sotomayor, Uber die Herkunft, passim; F. Nikolasch, Zur Deutung der „Dominus legem - dat"- Szene, RQ 64 (1969) 35-73; P.Testini, La lapide di Anagni con la „Traditio legis". Nota sull'origine del tema, „Archeologia classica” 25-26 (1973-1974) 718-740 (bibl.).

${ }^{68}$ Zdaniem P. Franke (Traditio legis und Petrusprimat, VigCh 26:1972, 267) „,bei der traditio legis eschatologische und primatsbezogene Bildelemente unvermittelt nebeneinander auftauchen".

${ }^{69}$ Piotr trzyma oparty na ramieniu krzyż o długim trzonku. Aż do końca IV stulecia tylko jemu będzie przydawany ten atrybut, dopiero później przedstawiani z nim będą także inni męczennicy - zob. Pietri, Roma christiana, s. 1567-1571. 
ciągając ku Chrystusowi ręce przykryte tkaniną ${ }^{70}$, Apostoł przede wszystkim okazuje szacunek swemu Panu ${ }^{71}$. W geście tym może być jednak wyrażona również gotowość do przyjęcia od Niego czcigodnego daru, którym mógł być zwój z Prawem, czyli nauką głoszoną przez Jezusa ${ }^{72}$.

Piotr jest $\mathrm{z}$ pewnością jedną z głównych postaci kompozycji Dominus legem dat. Nie mniejsze jednak znaczenie ma tutaj Paweł, drugi z książąt apostołów, który wcześniej w ikonografii zdecydowanie ustępował Piotrowi ${ }^{73}$. W omawianej scenie jest on symetrycznym odpowiednikiem Piotra i również jego obecność - po prawicy Chrystusa ${ }^{74}$ - nie jest tu ani przypadkowa, ani drugorzędna ${ }^{75}$. Świadkami objawienia i triumfu Pana są w równej mierze obaj Apostołowie.

$\mathrm{Na}$ podkreślenie zasługuje łączenie Apostołów Piotra i Pawła w wielu wczesnochrześcijańskich tekstach, które wspominają o początkach rzymskiej wspólnoty. Już w Liście Klemensa Rzymskiego (koniec I wieku) zostali oni nazwani „największymi i najsprawiedliwszymi kolumnami Kościoła"76. W pismach z II wieku jednym tchem wymienia się ich obu, stawiając obok siebie zarówno ich postacie, jak i zasługi oraz, jak można się domyślać, w pewnym

${ }^{70}$ Por. Schumacher, ,Dominus legem dat”, s. 6n.

${ }^{71}$ Por. A. Dieterich, Der Ritus der verhüllten Hände, w: tenże, Kleine Schriften, Leipzig 1911, 440-448.

72 Zawartość tego pisma i rozumienie terminu „Prawo” (lex), może być przedmiotem dyskusji, ponieważ symboliczny charakter motywu zwoju dopuszcza różne wyjaśnienia, por. np. B. Iwaszkiewicz-Wronikowska, Gloszenie Stowa. Kilka uwag na temat motywu księgi w ikonografii wczesnochrześcijańskiej, VoxP 23 (2003) t. 44-45, 137n: „Zmartwychwstały Pan (Dominus) przekazuje Kościołowi nie tyle Prawo w postaci reskryptu, co raczej naukę zawartą w ewangeliach. Tak rozumieli zresztą Prawo między innymi Tertulian, który pisał: „Legem proprie nostram, id est Evangelium" (Monogamia 8, 1, CCL 2, 1239), Orygenes, dla którego Chrystus był „prawodawcą chrześcijan" (In Josue hom. 9, 4, PG 12, 874) i wielu innych autorów okresu wczesnego chrzescijaństwa. Nowe Prawo zawarte jest w Nowym Testamencie, świętej księdze chrześcijaństwa, którą przedstawiciel Kościola przyjmuje ręką okrytą tkaniną, co w starożytności było powszechnie rozumianym gestem adoracji. Obiektem adoracji jest Słowo (Logos), którego majestat objawia się w Chrystusie wcielonym".

${ }^{73}$ Jako odrębna postać obecny jest w sztuce dopiero od ok. pol. IV wieku na tzw. sarkofagach pasyjnych, por. M. Simon, L'apôtre Paul dans le symbolisme funéraire chrétiens, „Mélanges d'Archéologie et d'Histoire de l'École Française de Rome" 50 (1933) 156-182; Gerke, Petrus und Paulus, zwei bedeutende Köpfe, s. 316. Znaczące jest także wyróżnienie Piotra w podejmowanych w 1. pol. IV wieku przedsięwzięciach budowlanych - Paweł doczekał się świątyni porównywalnej z konstantyńską Bazyliką sw. Piotra na Watykanie dopiero w końcu IV wieku, za rządów "trzech cesarzy".

${ }_{74}$ O dyskusji na temat takiego usytuowania por. Pietri, Roma christiana, s. 1435, przyp. 4.

75 J. Kollwitz (Christus als Lehrer und die Gesetzesübergabe an Petrus in der konstantinischen Kunst Roms, RQ 44:1936, 45-66) słusznie zwrócił uwagę na to, że zwój przekazywany bywa przez Chrystusa nie tylko Piotrowi, ale też Pawłowi i Janowi. Jednakże tego rodzaju przykłady są marginalne, występują głównie poza Rzymem i mogą wynikać z jakiegoś szczególnego zamysłu autorów.

${ }^{76}$ Epistola ad Corinthios 5, 2, SCh 167, 108; por. J. Gnilka, Piotr i Rzym. Obraz Piotra w pierwszych dwu wiekach, tłum. W. Szymona, Kraków 2002, $250 \mathrm{n}$. 


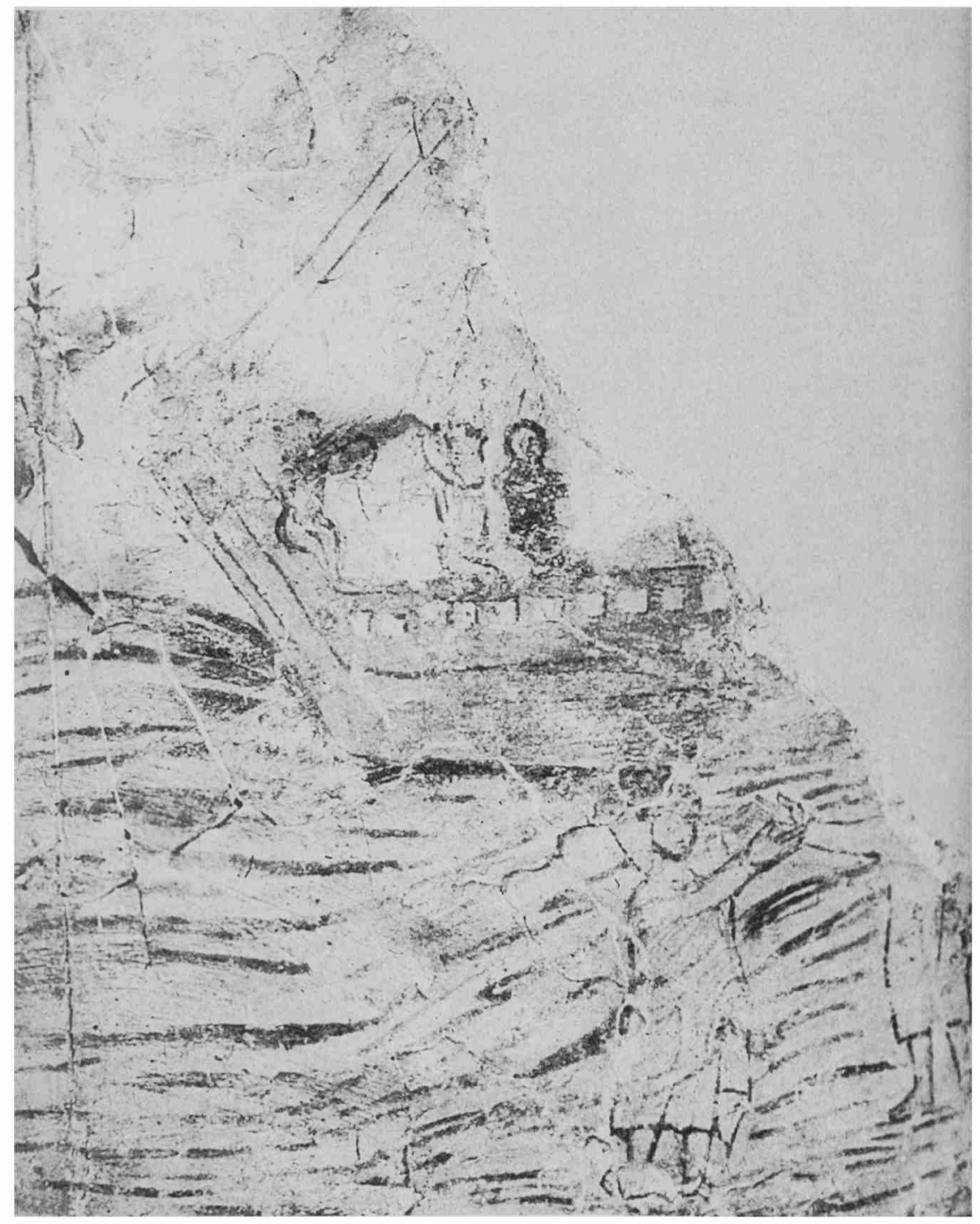

II. 1 


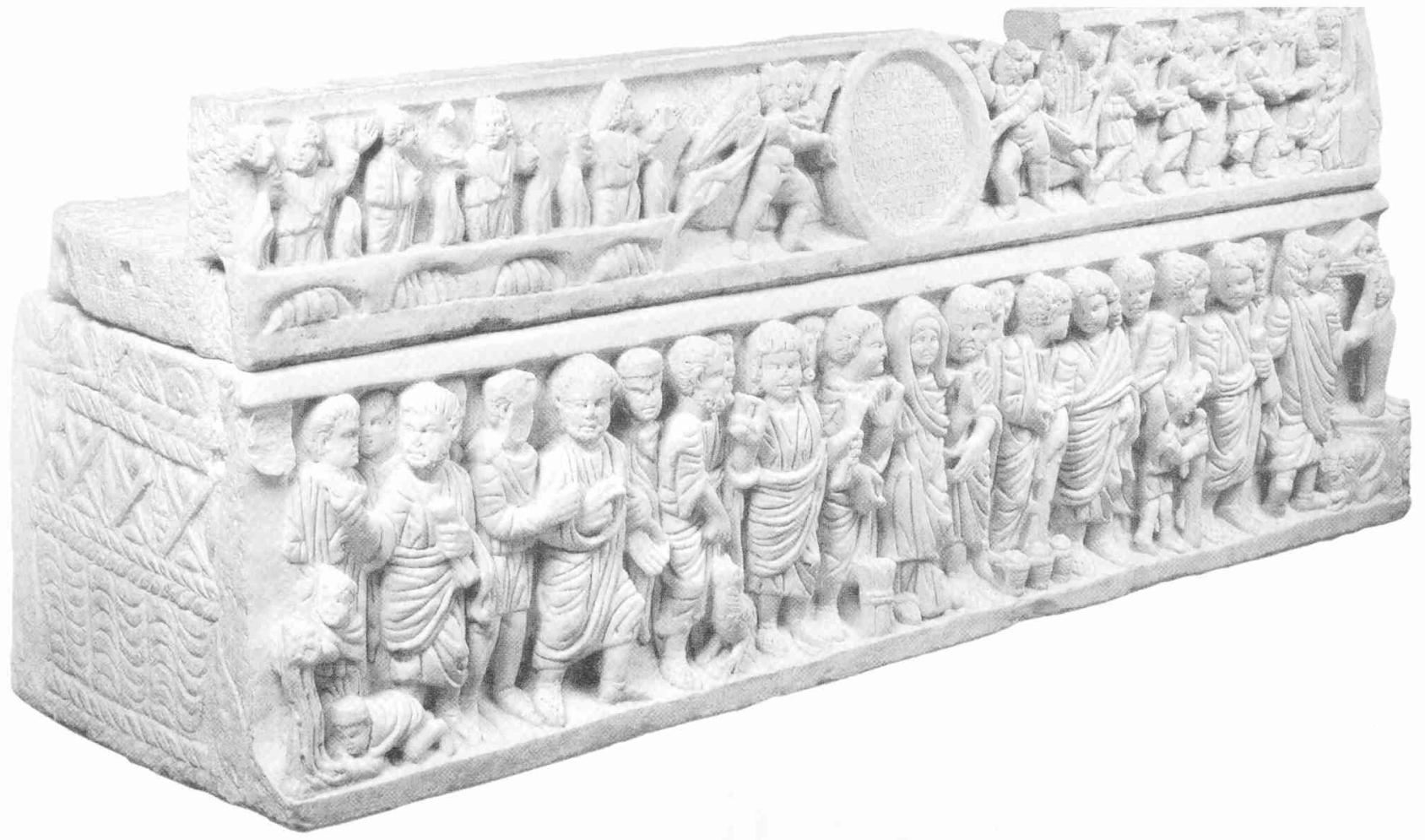

II. 2 


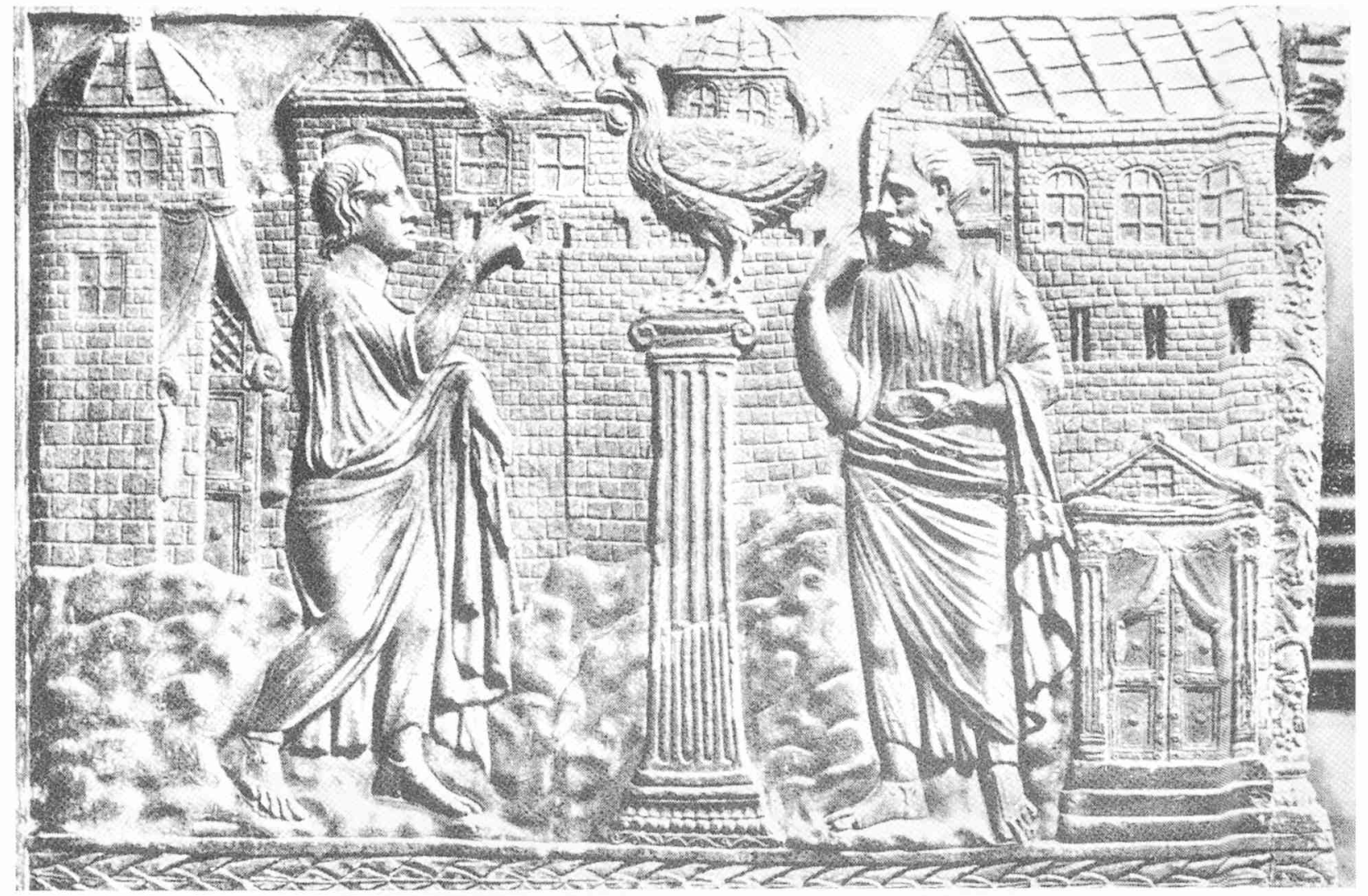




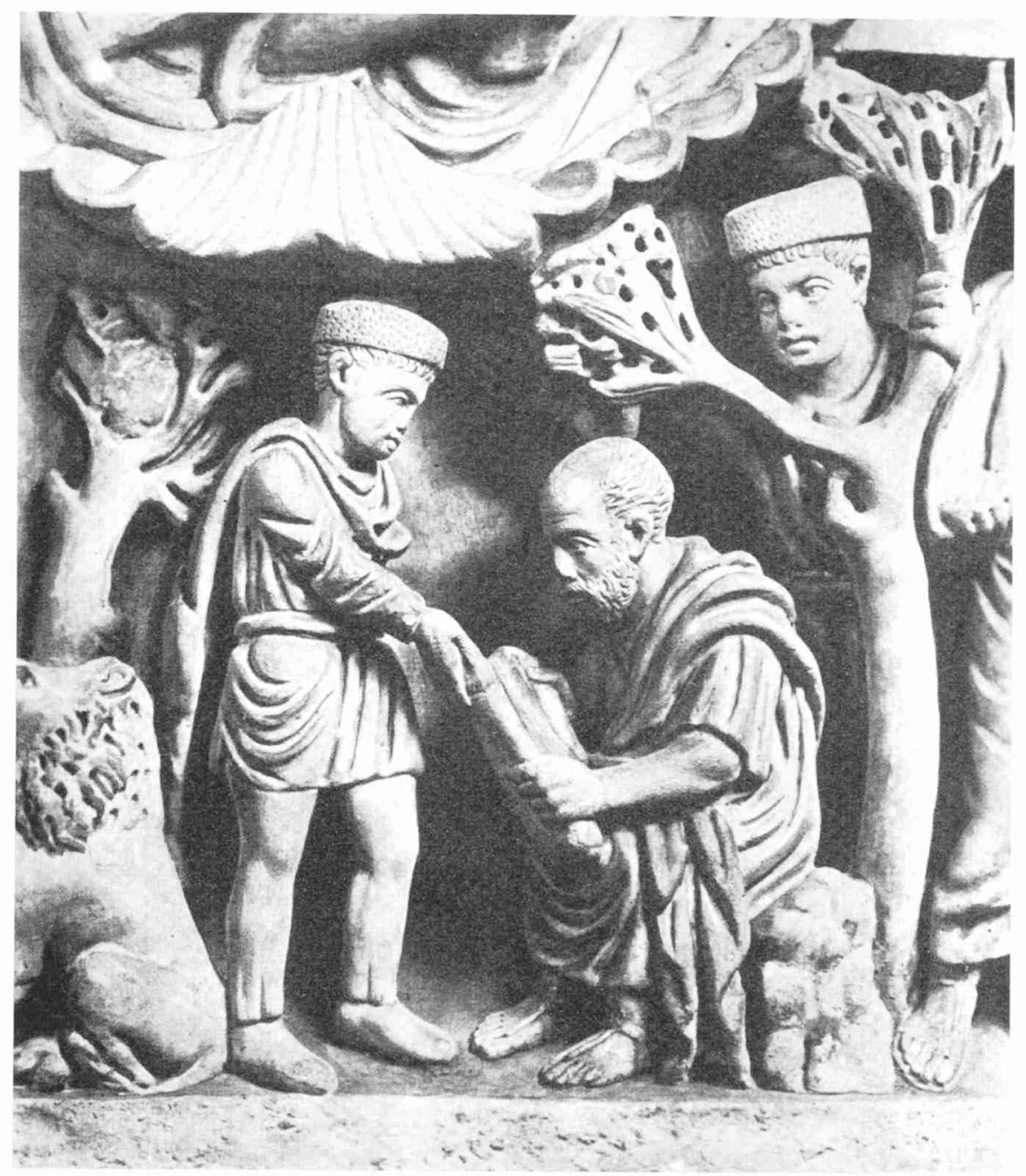

Il. 4 


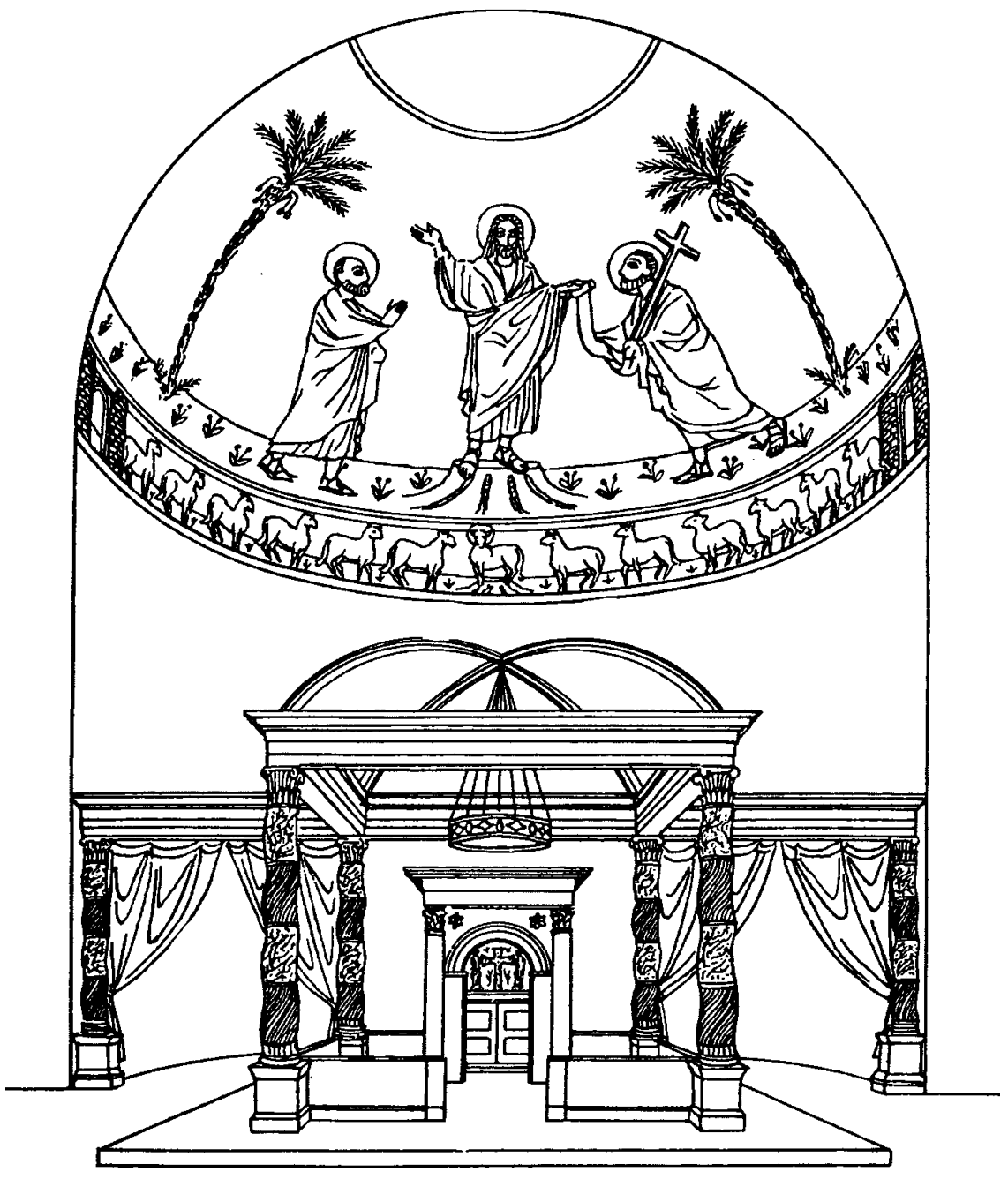

Il. 5 

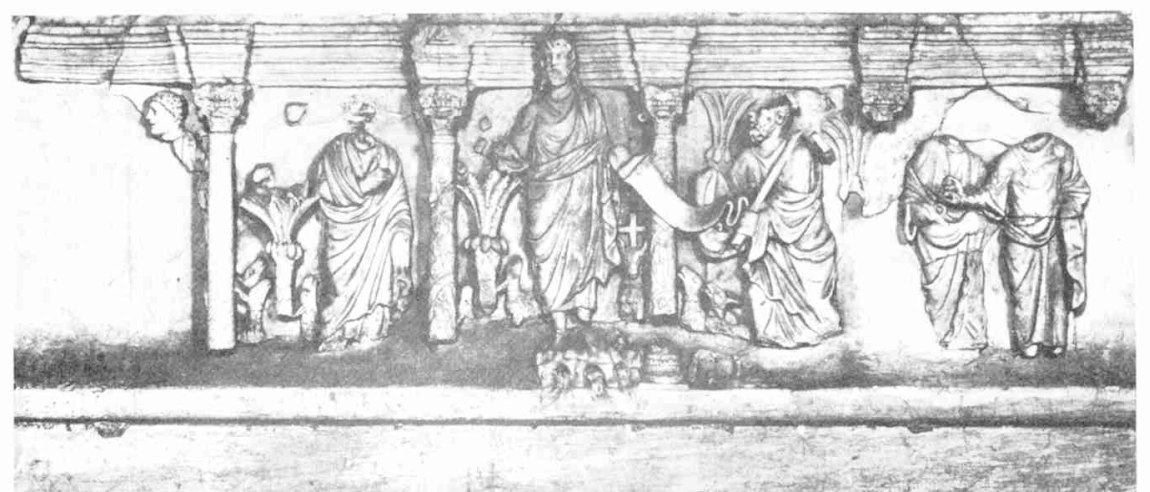

Il. 6

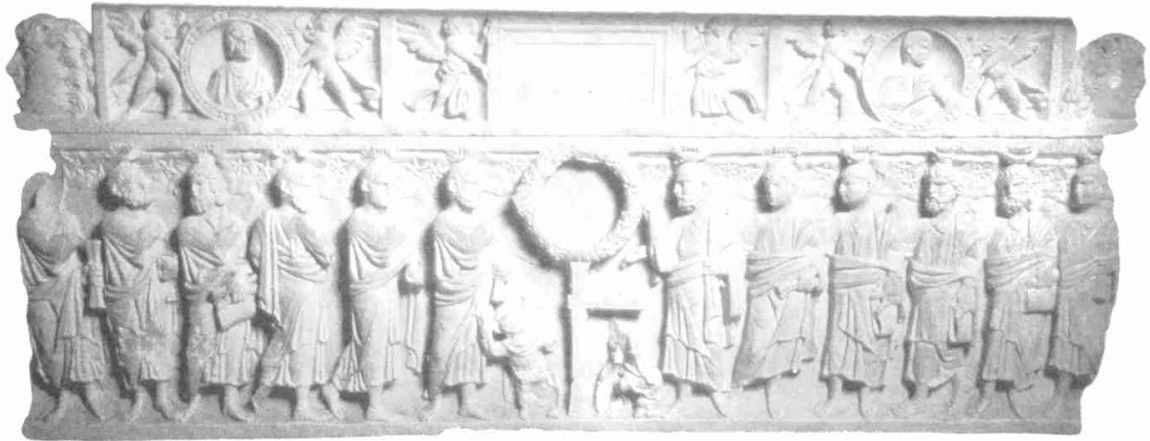

II. 7 

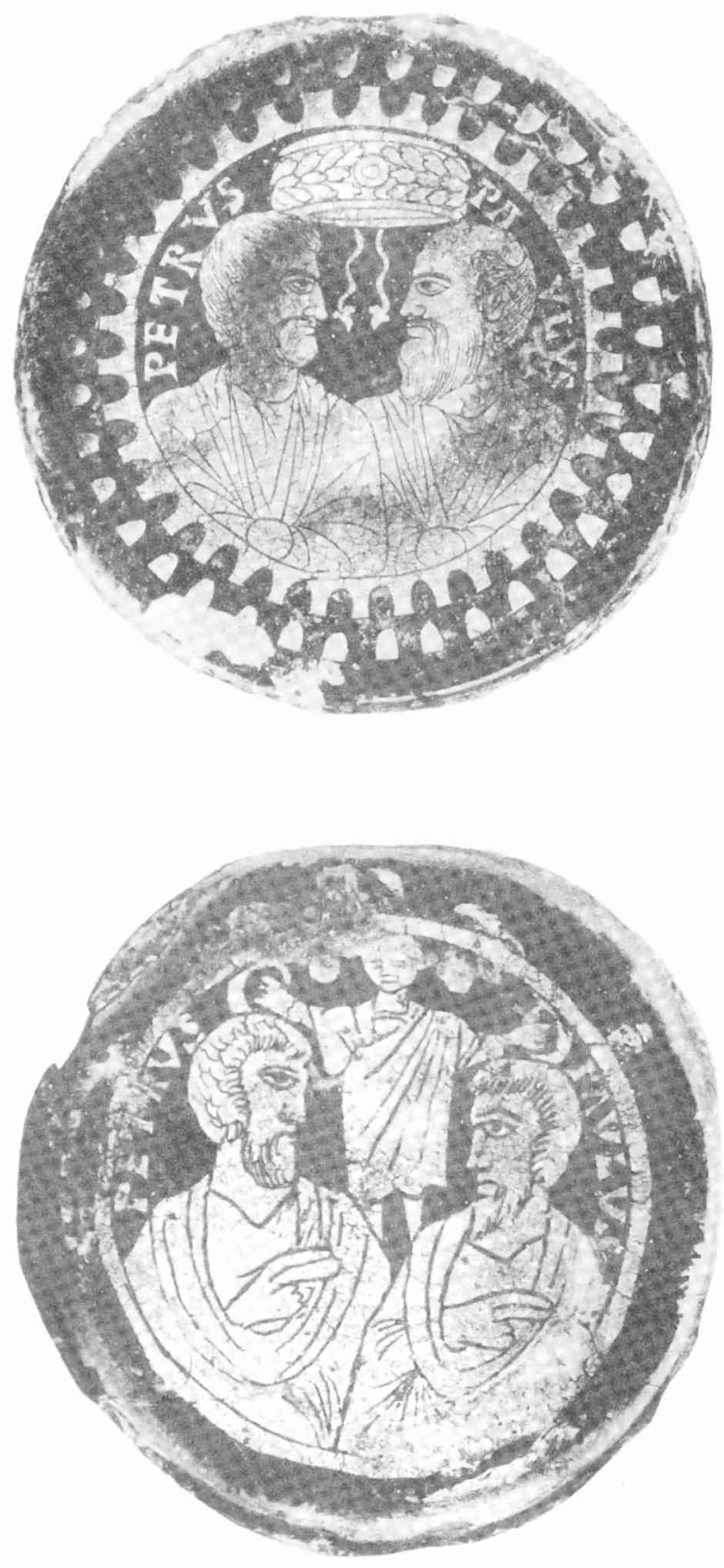

II. 8 


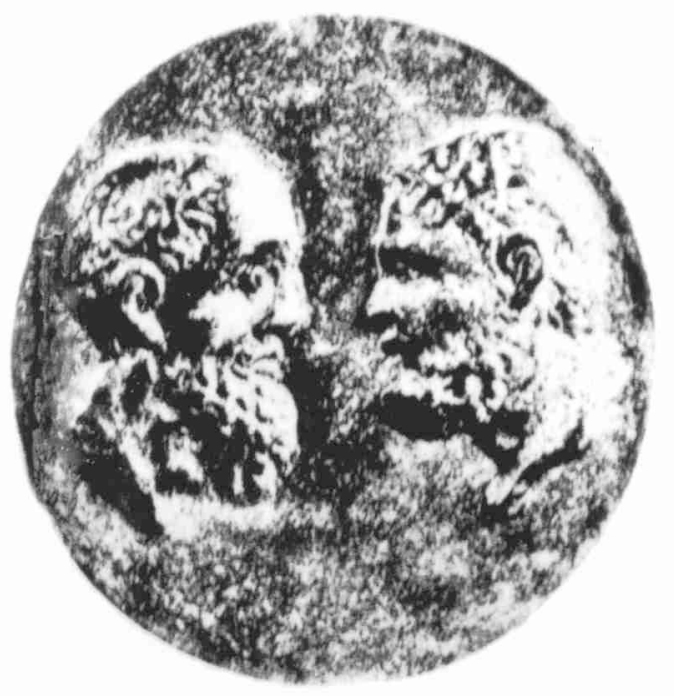

Il. 9

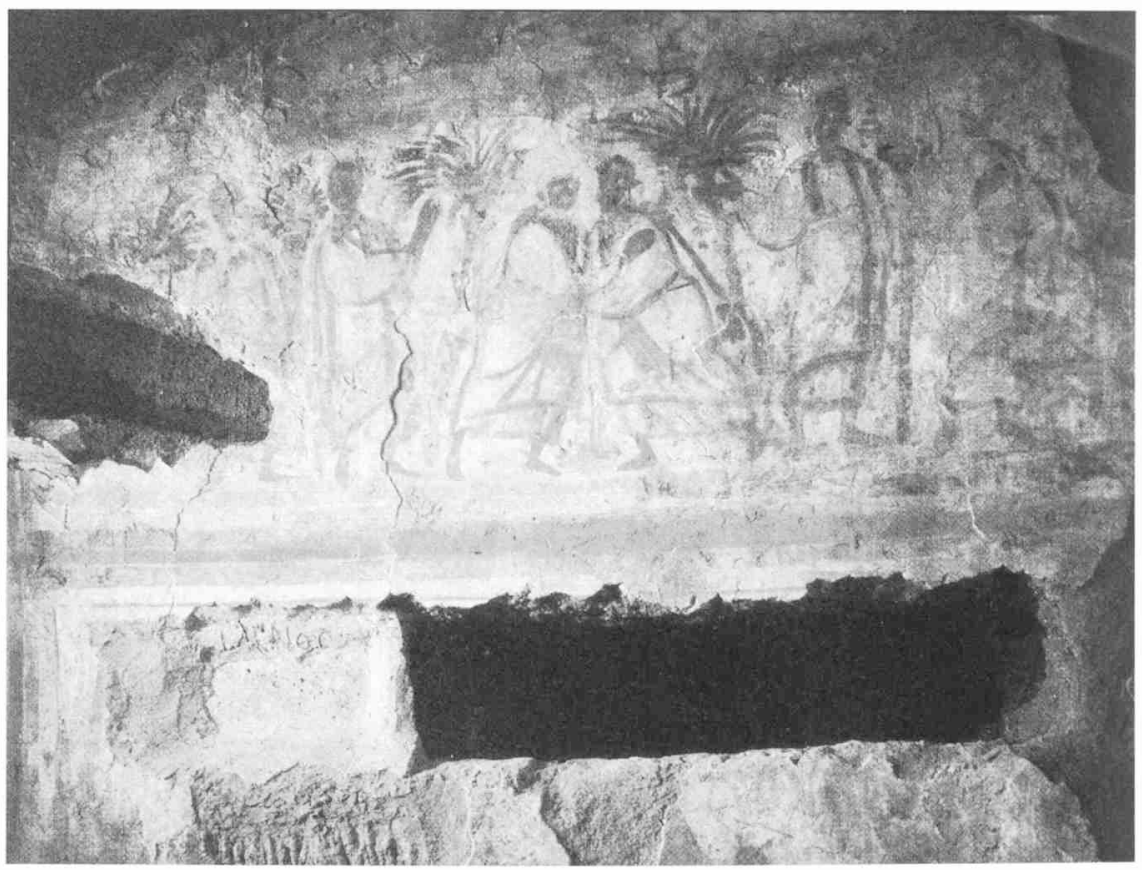

Il. 10 
sensie też i koleje losu. Wprawdzie teksty źródłowe nie dostarczają jednoznacznie sformułowanych dowodów, ale zawierają wystarczająco wiele poszlak, które pozwalają sądzić, że Piotr, tak jak Paweł, przebywał czas jakiś w stolicy Imperium oraz że obaj tu nauczali i obaj zginęli w Rzymie śmiercią męczeńską ${ }^{77}$. W III wieku czczono ich w jednym miejscu, ad catacumbas ${ }^{78}$, gdzie pozostawiono na ścianach setki skierowanych do nich inwokacji, zazwyczaj z formułą "Pawle i Piotrze módlcie się za...” (np. „Petre et Paule in mente habete in orationibus vestris", czy „Paule et Petre petite pro nobis omnibus”) ${ }^{79}$.

W sztuce wspólne występowanie założycieli Kościoła rzymskiego datuje się na 1. poł. IV wieku. W przedstawieniach Jezusa w otoczeniu apostołów (collegium apostolorum) ${ }^{80}$ postać Piotra, który powszechnie uważany był wówczas za pierwszego wśród nich (primus, princeps, primatus) ${ }^{81}$, wysuwa się wprawdzie na czoło, ale zawsze na równi $z$ Pawłem ${ }^{82}$. Obaj, trzymając w dłoniach zwoje, stoją lub siedzą tuż obok Tego, którego naukę głoszą. W 2. poł. IV wieku obserwujemy jeszcze bardziej wyraziste dążenie do łączenia przedstawień Piotra $z$ wizerunkami Pawła ${ }^{83}$. Friedrich Gerke pisał, że „Die Zeit des Zweibundes 'Christus-Petrus' wurde abgelöst durch die des Dreibundes: "Christus zwischen Petrus und Paulus""84. Apostołowie występują obok siebie nie tylko flankując postać Chrystusa, jak na przykład w scenach Dominus legem dat lub do niej podobnych, na tzw. sarkofagach pasyjnych, na których adorują centralnie umieszczony krzyż symbolizujący anastasis (il. 7$)^{85}$.

${ }^{77}$ Zestawienie źródel dotyczących tej problematyki i wnikliwą ich analizę zob. H. Lietzmann, Petrus und Paulus in Rom. Liturgische und archäologische Studien, Berlin - Leipzig 1927. Od czasu ukazania się tej pracy i w 25 lat później publikacji protestanckiego badacza O. Cullmanna (PetrusJünger - Apostel - Märtyrer, Zurich - Stuttgart 1952), na ogól uznaje się obecność i śmierć Piotra w Rzymie za co najmniej prawdopodobne, por. np. K. Aland, Petrus in Rom, „Historische Zeitschrift" 183 (1957) 497-516.

78 Por. B. Iwaszkiewicz-Wronikowska, Najstarsze świadectwa kultu męczenników w Rzymie, w: Sympozja Kazimierskie, IV, Lublin 2004, 151-152; E. Jastrzębowska, Miejsca święte Piotra i Pawta w Rzymie w III i IV wieku, w: tamże, V (w druku).

79 Por. ICVR V 12912; 12918.

80 Niektórzy badacze widzą Piotra i Pawla również w osobach towarzyszących orantkom na sarkofagach jednofryzowych (np. Gerke, Petrus und Paulus, zwei bedeutende Köpfe, s. 328). Nie jest to jednak interpretacja przekonująca, por. Testini, Gli apostoli Pietro e Paolo, s. 110n.

81 Por. Pietri, Roma christiana, s. 1459-1466.

82 Por. P. Testini, Osservazioni sull'iconografia del Cristo in trono fra gli apostoli, „Rivista dell'Istituto di Archeologia e Storia dell'Arte" 11-12 (1963) 230-300; R. Knapiński, Typologia przedstawień Collegium Apostolorum w sztuce pierwszego tysiąclecia, VoxP 11-12 (1991) t. 2021, 48-71.

83 Por. Ch. Pietri, Concordia Apostolorum et renovatio Urbis (culte des martyrs et propagande pontificale), „Mélanges d'archéologie et d'histoire” 73 (1961) 275-322.

84 Gerke, Petrus und Paulus, zwei bedeutende Köpfe, s. 317.

85 Por. P. Skubiszewski, La croix dans le premier art chrétien, Paris 2002, 24-35; zob. też przedstawienie Piotra i Pawła w scenie hetimasia - np. na mozaice na luku triumfalnym w S. Maria Maggiore w Rzymie. 
Na medalionach ${ }^{86}$, szkłach złoconych $^{87}$, w ceramice ${ }^{88}$ przedstawiano zestawione w parę wizerunki Piotra i Pawła, pokazując ich ze zwojami ${ }^{89}$ lub, na wzór rzymskich urzędników, ze znakami zwycięstwa (palmy i wieńce), które tym razem miały być aluzją do męczeństwa i triumfu nad śmiercią (il. 8$)^{90}$. Czasami pomiędzy Piotrem a Pawłem umieszczano kolumnę, symbol duchowej siły i jedności założycieli Kościoła rzymskiego ${ }^{91}$.

$\mathrm{Na}$ medalach kommemoracyjnych, być może przeznaczonych na prezenty wręczane z okazji wspólnego święta obu Apostołów obchodzonego 29 czerw$\mathrm{ca}^{92}$, które produkowano w Rzymie w okresie od połowy IV do początków $\mathrm{V}$ wieku, spotyka się także popiersia Piotra i Pawła zwrócone ku sobie profilem (il. 9), a więc nawiązujące do typu ikonograficznego, który na rzymskich monetach, szkłach i sarkofagach wyobrażał ideę zgody (concordia) ${ }^{93}$. Tę samą myśl wydają się wyrażać przedstawienia Piotra i Pawła w uścisku94: np. malowidło niedawno odkryte w katakumbie w ex Vigna Chiaraviglio (il. 10) ${ }^{95}$, plakietka z kości słoniowej z Castellamare di Stabia $(\mathrm{Vw} .)^{96}$, znane z akware-

${ }^{86}$ Por. Testini, L'iconografia degli apostoli, nr 65, il. 12, s. 301; nr 77, s. 303; nr 64, s. 301; Donati, Pietro e Paolo, nr 61-63, s. 140n. i 207n.

${ }^{87}$ Por. Zanchi Roppo, nr 204, 211, 154, 123, 205, 213, 202, 220, 222, 232; Donati, Pietro e Paolo, nr 85-94, s. 162-167 i 221-225. Według Pietri (Concordia Apostolorum, s. 279): „l'accord s'est fait depuis Vopel (H. Vopel, Die altchristliche Goldgläser, Freiburg i. Br. 1899) pour dater les verres représentant Pierre et Paul du milieu du IVe siècle aux premières décades du $\mathbf{V}^{e}$ siècle".

${ }^{88}$ Por. F. Bejaoui, Pierre et Paul sur de nouveaux fragments de céramique africaine, RivAC 60 (1984) 45-62.

89 Por. Pietri, Roma christiana, s. 1575 n.

90 Por. Concordia Apostolorum, s. 279nn; Bejaoui, Pierre et Paul, s. 60n.

${ }^{91}$ Por. Columna, w: Thesaurus Linguae Latinae III 1741n ; Pietri, Concordia Apostolorum, s. $281 \mathrm{n}$.

92 Por. Pietri, Roma christiana, s. 1573n.

93 Por. Grabar, dz. cyt., s. 66n: „Les médaillons des deux apôtres sont des copies de médaillons romains contemporains qui montrent, comme eux, les visages vus de profil, et tournés l'un vers l'autre, de deux empereurs, de deux dieux, ou de deux héros (les Dioscures)"; Pietri, Concordia Apostolorum, s. 284-291.

94 P. Testini (L'iconografia degli apostoli Pietro e Paolo nelle cosidette 'arti minori', s. 284) i F. Bisconti (Pietro e Paolo: l'invenzione delle immagini, s. 53) widzą tu nawiązanie do tekstu apokryficznego opowiadającego o spotkaniu Piotra i Pawła, jakie miało miejsce przed ich męczeństwem, por. B. Mombritius, Epistula Beati Dionisii Areopagite de morte Apostolorum Petri et Pauli ad Thymoteum, Paris 1910, s. 354nn. Innego zdania jest H.L. Kessler (The Meeting of Peter and Paul in Rome: An emblematic narrative of spiritual Brotherhood, "Dumbarton Oaks Paper" 41:1987, 267), który uważa, ze przedstawiono tu spotkanie obu Apostołów po przybyciu Pawła do Italii.

95 Por. F. Bisconti, L'abbraccio tra Pietro e Paolo ed un affresco inedito del cimitero romano dell'ex Vigna Chiaraviglio, w: 42. Corso di cultura sull'arte ravennate e bizantina, Ravenna 1995, 71-93.

96 Por. Testini, L'iconografia degli apostoli Pietro e Paolo nelle cosidette 'arti minori', s. 281284, il. 31; Dizionario patristico, s. 176, il. 73; Donati, Pietro e Paolo, nr 55, s. 134 i 211. 
lowej kopii przedstawienie z bazyliki S. Paolo fuori le Mura ${ }^{97}$, oraz wiele innych, późniejszych ${ }^{98}$. Tego typu przedstawienia przypominają też wizerunki członków jednej rodziny, zjednoczonych uczuciem wzajemnej miłości i szacun$\mathrm{ku}^{99}$. Tak ukazywano również więzy braterstwa pomiędzy współrządzącymi władcami (concordia fratrum) ${ }^{100}$.

Charles Pietri znakomicie wykazal, zarówno w oparciu o materiał ikonograficzny, jak i w tekstach autorów chrześcijańskich z IV wieku, że Piotra i Pawła pokazywano jako współtwórców rzymskiego Kościoła, niezbędnych w dalszym jego rozwoju - Piotr otwiera bramy niebios tym, którzy przyjęli naukę głoszoną przez Pawła ${ }^{101}$; obaj przybyli ze Wschodu, ale ponosząc śmierć męczeńską w Rzymie zostali tym samym jego obywatelami; zrządzeniem opatrzności położyli fundamenty pod budowę stolicy chrześcijaństwa, są jej chwałą i prawdziwymi herosami - protektorami Miasta ${ }^{102}$; dzięki ich opiece i wstawiennictwu, Rzym stał się godny miana caput Ecclesiae ${ }^{103}$. Podsumowując, można by powiedzieć cytując słowa Joachima Gnilki, że „narastające szczególne uznanie dla Kościoła rzymskiego miało podstawy w męczeństwie - Piotra i Pawła oraz pierwszych rzymskich męczenników"104.

Idę̨ Rzymu, jako miasta Piotra i Pawła, którzy byli braćmi poprzez braterstwo krwi przelanej w męczeńskiej śmierci, głosił przede wszystkim biskup Damazy (368-384) ${ }^{105}$, skutecznie konfrontując ją z ideą pogańskiej stolicy otaczanej opieką przez braci Dioskurów ${ }^{106}$. Koncepcję tę utrwalili następcy Damazego - m. in. Sykstus III (432-440r.), łącząc imiona Apostołów w inskrypcji przeznaczonej dla dedykowanego im obu koscioła ${ }^{107}$ i Leon Wielki (440-461r.),

${ }^{97}$ Por. Biblioteca Apostolica Vaticana, Cod. Barb. Lat. 4406, fol. 126r; S. Waetzold, Die Kopien des 17. Jahrhunderts nach Mosaiken und Wandmalereien in Rom, Wien - München $1964,55 n$.

98 Ciekawe przyklady pokazujące trwanie w Bizancjum i średniowiecznej Europie tego typu ikonograficznego oraz reprezentowanej w nim idei zob. Kessler, The Meeting of Peter and Paul in Rome, s. 265-275; A. Grzybkowski, Concordia apostolorum - gotycka rzeźba w Legnicy, w: tenże, Między formq a znaczeniem. Studia z ikonografii architektury i rzeźby gotyckiej, Warszawa 1997, 158-167.

99 Por. Pietri, Concordia Apostolorum, s. 282n.

100 Przykladem jest posag tetrarchów z Wenecji, por. R. Delbrück, Antike Porphyrwerke, Berlin - Leizig 1932, pl. 31 - 37.

101 Por. Pietri, Concordia Apostolorum, s. 295.

102 Por. Pietri, Concordia Apostolorum, s. 297-317; tenże, Roma christiana, s. 1557.

103 Por. Pietri, Concordia Apostolorum, s. 322.

104 Gnilka, dz. cyt., s. 251.

105 Por. B. Wronikowska, Rzym papieża Damazego, „Meander” 51 (1996) 73-77.

106 Por. plakietkę z kości słoniowej w Muzeum w Trieście - zob. Testini, L'iconografia degli apostoli Pietro e Paolo nelle cosidette 'arti minori', s. 283.

107 Por. G.B. De Rossi, Inscriptiones Christianae Urbis Romae, II/1, Roma 1888, s. 110, n. 67: „Haec Petri Paulique simul nunc nomine signo/ Sixtus apostolicae sedis honore fruens./ Unum quaeso pares unum duo sumite munus,/ Unus honor celebrat quos habet una fides". 
nazywając ich nowymi założycielami Miasta, jako „sancti patres verique pastores”, którzy Rzym - „magistra erroris” przekształcili w „discipula veritatis”"108.

Myślę, że właściwym bohaterem IV-wiecznych przedstawień Piotra i Pawła był Rzym chrześcijański i jego biskup, jako sukcesor w linii prostej obu, zgodnie działających, fundatorów Kościoła rzymskiego. To dzięki tej sukcesji miał on prawo do przewodzenia Kościołowi powszechnemu ${ }^{109}$.

\title{
THE ELDEST PRESENTATION OF ST. PETER APOSTLE AND PROBLEM OF PAPAL PRIMACY
}

\author{
(Summary)
}

The article, which is contained with two parts, treats of the eldest iconography of St. Peter in relation to papal primacy. The author of this article reliances on this iconography and proves that this primacy concerned not only St. Peter but also St. Paul because both of them were founders of Roman Church.

${ }^{108}$ Por. Sermo 82, 1, PL 54, 422C.

109 Por. Pietri, Concordia Apostolorum, passim; Testini, L'iconografia degli apostoli Pietro e Paolo nelle cosidette 'arti minori', s. 285. 